\title{
凍上被害箇所における路床土の 地盤工学的性質とその評価
}

\author{
川端伸一郎 ${ }^{1} \cdot$ 亀山修一 ${ }^{1} \cdot$ 佐藤厚子 ${ }^{2}$ \\ 1 正会員 博士（工） 北海道科学大学 工学部（广006-8585 札幌市手稲区前田 7 条 15 丁目 4-1） \\ E-mail : kawabata@hus.ac.jp \\ 2 正会員 博士（工） 土木研究所 寒地土木研究所（一062-8602 札幌市豊平区平岸 1 条 3 丁目 1-34）
}

\begin{abstract}
凍上被害を受けた北海道内の国道より路床土（48 試料）をサンプリングし，凍上性および地盤工学的な特性 を調査した. 凍上被害箇所の路床土は $80 \%$ 以上が粗粒土であり, 締固めに適した良質なものが多く存在した. しかし, 細粒分含有率の変動を調べると, 数 $100 \mathrm{~m}$ の範囲で大きく変化する例も確認されたことから, 不同凍上 による路面の段差や波打ちにつながる恐れも懸念された．凍上被害を受けた箇所の路床土には，非凍上性のも のは含まれず，大部分が強凍上性に判定され，さらに極めて強い凍上性を示寸試料も多くみられた．簡易的な 指標によって凍上性の判定を試みた結果，凍上性の強弱を表寸强熱減量（質的な凍上リスク）と凍上性への影 響度を表す細粒分含有率（量的な凍上リスク）を組み合わせて用いることが有効であった.
\end{abstract}

Key Words : frost heave, subgrade soil, fine fraction, consistency, ignition loss

\section{1. はじめに}

北海道などの寒冷地の道路では，冬期に路床が凍結す ることで, 凍上による路面の隆起やクラックが発生する 被害が多く報告されている ${ }^{1) 33}$. 凍上は, 路面の平坦性を 悪化させ車両走行の安全性や乗り心地に影響を与え，さ らに表層のクラックにまで発展すると舗装寿命を大幅に 低下させてしまう. 近年においても2017 年度には, 異常 低温による凍上災が認定されており, 道路の凍上問題は, 寒冷地における舗装の設計や維持管理上の継続的な課題 と認識されている.

現在の舗装設計では, 凍上対策として理論最大凍結深 さの $70 \%$ までを非凍上性材料に置き換える置換工法が採 用されている4).ここで, 理論最大凍結深さとは, 均一な 砕石で地盤を構成した場合の凍結深さであり, 最大值を 想定した設計上の仮想凍結梁さである.

このように置換え深さを $70 \%$ に減ずるのは, 路床の一 部が凍上を起こしても路面に有害な変位は生じないとす る過去の調查に基づいたものである5。

しかし，現在でも凍上被害が顕在化していることや埔 装に対する要求性能が時代と共に向上していることを勘 案すると, 凍上対策工法も見直しの段階にあるといえる. このような検討には，凍上被害の実態とその原因である
路床土の凍上性の関係を明らかにすることが重要であり， これにより, 将来的には一律 $70 \%$ の置換ではなく, 路床 土の凍上性に応じた合理的な置換率の設定が可能になる と考えられる.

そこで本論文は，凍上被害を受けた北海道内の国道よ り路床土をサンプリングし，凍上被害と凍上性の関係を 明らかにすると共に，路床土の凍上性を簡易に判定する 手法について検討したものである.

\section{2. 路床の設計と現行の凍上対策工法}

\section{(1) 路床に関するアスファルト舗装の構造設計 4)}

アスファルト舗装における構造設計では, 古くから経 験にもとづく $\mathrm{T}_{\mathrm{A}}$ 法が多く用いられてきた. $\mathrm{T}_{\mathrm{A}}$ 法では路床 を設計 CBR により規定し, CBR が 3\%以上であることを 条件にしている. なお，CBR 以外には材料の規格は特に 要求していない.

ただし, 寒冷地である場合は, 路床に凍結が及ぶか否か を判定し, 凍結の可能性があれば凍上対策の必要性を検 討する.

(2) 凍上対策工法 


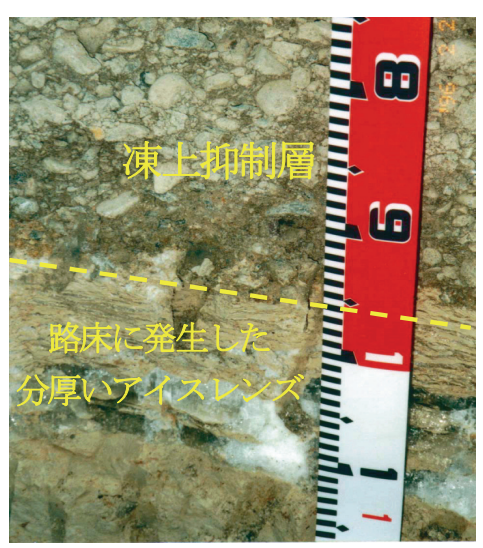

写真-1 路床に発生したアイスレンズ

路床に凍結が及ぶ場合は，路床土の凍上試験を実施す る.これにより凍上の恐れがあれば, 凍上対策を施すが， 通常はほぼ例外なく理論最大凍結深さの $70 \%$ までを非凍 上性材料に置き換える置換工法が採用される ${ }^{6}$.

ここで，置換え深さを $70 \% に$ に減ずるのは，1950 年代に 実施された砂利道の凍上観測 5) が根拠になる. 当時の観 測では，深さごとに生じた凍上変位と路面変位の関係を まとめ, ある深度以深で生じた凍上変位は路面変位に与 える影響が少ないことを示した. この結果を基に, 後に設 計手法が確立され，理論最大凍結深さの $70 \%$ が提唱され た 7). 写真-1 は実際の路床に生じたアイスレンズ（凍上 を引き起こす水層）である. 置換え深さを $70 \%$ とするこ とで, 路床の一部は凍結寸ることになるが, この深さで生 じた凍上変位は上層には伝わらないとする考えである.

深部で生じた凍上変位が路面変位に与える影響が少な くなるのは，上層部が凍土層になることで変位が拘束さ れ，下層の未凍結側に変位が吸収されるためと考えられ る. また，当時の観測結果からは，路面変位は最大凍結深 さとの比で $60 \%$ までの凍結によって生じた凍上に支配的 で, 70\%程度から次第に影響が少なくなるとしている5)。 ただし, それらの結果のバラつきは大きく, 要因としては 凍結深さだけでは表現しきれない地盤の凍上性の違いに よるものと考えられる.

凍上対策工法の設計における凍上試験の役割は，凍上 対策の要否を判断するのみであり, 設計用值としての利 用には至らない，しかし，現在の道路土工要綱のを境に， 凍上試験は地盤工学会によって 2003 年に基準化された高 精度な試験 8)を優先的に選択するよう改訂がなされた.こ の試験で得られる結果は，旧式な試験法9)とは異なり，再 現性も良く土質定数として信頼性の高いものである ${ }^{10)}$.

高度な凍上性評価が可能な現状において，より合理的 な凍上対策を再考するには，一律 $70 \%$ 置換ではなく, 路床の凍上性に応じた置換率の変更を視野に検討寸るこ とが重要である.
表-1 サンプリング箇所の概要

\begin{tabular}{c|c|c|c|c}
\hline 地 方 & $\begin{array}{c}F \\
\left({ }^{\circ} \mathrm{C} \cdot \text { days }\right)\end{array}$ & $\begin{array}{c}\text { 延長 } \\
(\mathrm{km})\end{array}$ & 試料数 & $\begin{array}{c}\text { 凍上試験 } \\
\text { 実施数 }\end{array}$ \\
\hline \hline 石狩地方 & 797 & 22 & 5 & 4 \\
\hline 十勝地方 & 918 & 6.5 & 3 & 3 \\
\hline 十勝地方 & 954 & 3.6 & 8 & 7 \\
\hline 十勝地方 & 960 & 10 & 6 & 3 \\
\hline 宗谷地方 & 1072 & 14.9 & 4 & 3 \\
\hline 上川地方 & 1095 & 2.3 & 6 & 1 \\
\hline 十勝地方 & 1237 & 44.4 & 16 & 2 \\
\hline \multicolumn{5}{|c|}{$F:$ 近隣アメダスによる 10 年確摔凍結指数 }
\end{tabular}

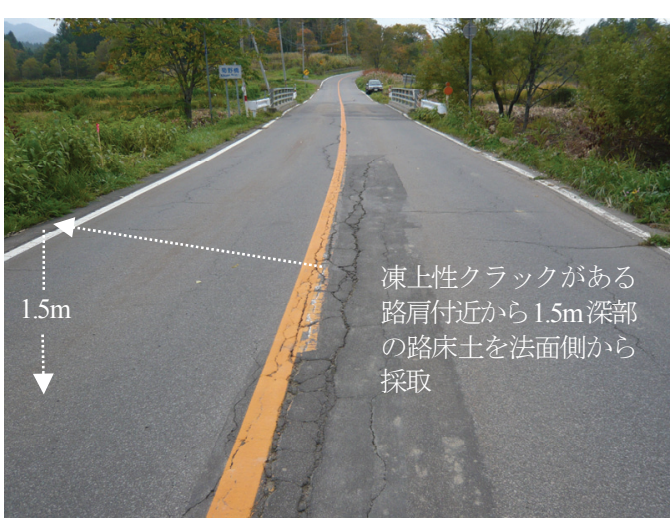

写真-2 サンプリング箇所の一例

\section{3. 試料と実験方法}

\section{(1) サンプリング䇢所の選定とサンプリング方法}

路床土のサンプリングは，過去に実施した凍上の被害 調査結果 ${ }^{3)}$ から路線を選定し, 北海道全域の国道で実施し た．表-1 はサンプリング箇所の概要である．本調査では 凍結指数の異なる 7 路線 (4 地方) において, 凍上被害が みられた箇所で計 48 試料を採取した。

試料採取の条件は，典型的な凍上による縦断クラック がみられること, 歩道を有さない郊外路線であること, 盛 土であり路床に相当寸る深度の試料を盛土法面側から採 取可能であること，とした。 なお, 法面側からの試料採取 は，表-1 の凍結指数から想定される置換え深さを考慮し て, 路面から $1.5 \mathrm{~m}$ 下がりで草根が混入しない部分まで表 層を除去した後にサンプリングを実施した．写真-2 は， サンプリング箇所の一例である.

改めて本報告における路床土とは，厳密にはクラック 直下の路床土ではなく, クラック周辺の路床深度に相当 する盛土材である. なお，一つの被害箇所では 1 サンプ リングとして，サンプリング間䛿は最低でも $0.1 \mathrm{KP}(100$ m）以上を確保した. 


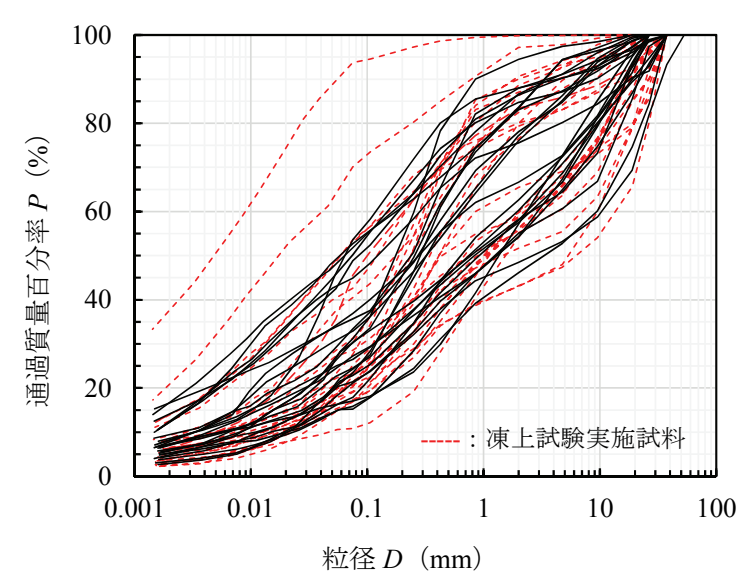

図-1試料の粒径加積曲線

\section{（2）実験方法}

実施した試験は，粒度試験，強熱減量試験，液性限界・ 塑性限界試験, 地盤工学会 (JGS) 基準の凍上試験である.

図-1 は試料の粒径加積曲線であり，破線は凍上試験実 施試料を表している. なお，粒度試験以外は，最大粒径の 制約を受けるものもあるため, $2 \mathrm{~mm}$ 以下の尖頭粒度で再 調整した試料を用いた.

凍上は細粒分によって引き起こされる現象である.こ のため, 細粒分の量とその性質は特に注目すべきである.

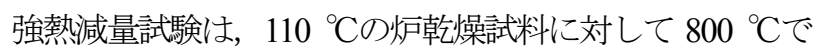
1 時間加熱した際の減量である. これは, 無機質な土であ れば土粒子表面に強吸着された水量に近い值と考えてよ い. 凍上が発生するには, $0{ }^{\circ} \mathrm{C}$ 以下でも凍らない不凍水す なわち吸着水の存在が不可欠である. このため, 強熱減量 は凍上性と深く関連すると考えられ, 従来から火山灰土 の凍上性判定などに利用されてきた ${ }^{11)}$.

コンシステンシー限界（液性限界・塑性限界）は，水分 量による土の硬軟を示す物理指標であり, (1)粒度組成, (2) 粒子形状, (3)比表面積, (4)粘土鉱物の種類と含有量, (5)間 隙水中の塩類の種類と濃度, 6)粒子表面の電荷の強さと 吸着水層の厚さ, (7)有機物の種類と含有量, に影響を受け るとされる 12). 特に(3)や6に挙げられた影響因子は, 凍 上の支配因子との関連が強い.

図-2 はJGS 法の凍上試験装置である.JGS 法は，供試 体上端面を $0{ }^{\circ} \mathrm{C}$ に保ちながら下端面の温度を徐々に降下 させ，一定速度で涷結線 $\left(0{ }^{\circ} \mathrm{C}\right.$ 線 $)$ を供試体内で移動させ る. この際の凍結速度は 1〜2 mm/h と定めている. なお, 実現象と異なり凍結方向を下方から行うのは，モールド と供試体の凍着による摩擦を軽減する工夫である. 凍上 性の評価は, 凍上量一時間曲線の最急勾配から求められ る凍上速度を用いる. 評価基準は, 凍上速度 $U_{\mathrm{h}}(\mathrm{mm} / \mathrm{h})$ が 0.1 未満で涷上性が低い，0.3 以上で高い，両值間は中位 となる。

今回のサンプリングでは，現場の密度は測定していな

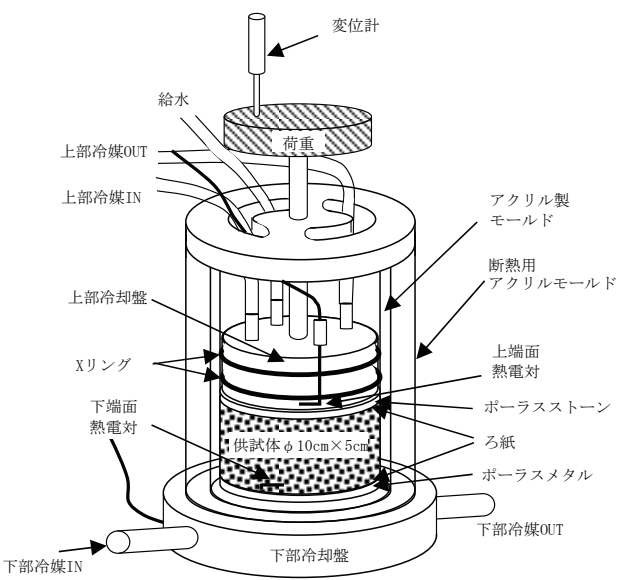

図-2＼cjkstart地盤工学会（JGS）基淮の凍上試験装置

表-2 凍上試験の供試体密度と含水比

\begin{tabular}{c|c|c|c}
\hline 地 方 & $\begin{array}{c}\text { 凍上試験 } \\
\text { 実施数 }\end{array}$ & $\begin{array}{c}\text { 供試体 } \\
\text { 平均乾燥密度 } \\
\left(\mathrm{g} / \mathrm{cm}^{3}\right)\end{array}$ & $\begin{array}{c}\text { 供試体 } \\
\text { 平均含水比 } \\
(\%)\end{array}$ \\
\hline \hline 石狩地方 & 4 & 1.40 & 32.0 \\
\hline 十勝地方 & 3 & 1.18 & 32.4 \\
\hline 十勝地方 & 7 & 1.43 & 34.1 \\
\hline 十勝地方 & 3 & 1.24 & 36.8 \\
\hline 宗谷地方 & 3 & 1.31 & 37.4 \\
\hline 上川地方 & 1 & 1.20 & 45.9 \\
\hline 十勝地方 & 2 & 1.34 & 33.3 \\
\hline
\end{tabular}

い.このため, 凍上試験の供試体は，自然含水比条件で $100 \mathrm{kPa} の$ 静的締固め（目標厚 $5.0 \mathrm{~cm} / 2$ 層）によって作製 した. また, 凍上試験は, サンプリング量の関係などで, 全 48 試料中 23 試料に限られる（表-2）.

\section{4. 結果と考察}

\section{（1）凍上被害を受けた路床土の物理的性質}

図-3に凍上被害箇所の路床土 (全 48 試料) の土質分類 を，図-4に細粒分含有率の分布を示す. 本試料群は, $83 \%$ が粗粒土であり，その内訳としては礫質土と砂質土がほ ぼ同数である．また，細粒分含有率は 20～30\%程度のも のが多く, 粒度組成から考えると盛土材としては, 締固め に適した良質なものが多いと推察される.

一方で細粒土が 8 試料 $(17 \%)$ 含まれており，極端に 細粒分が多いものは，試料を法面から採取したため法面 整形用の路床土とは異なる材料が含まれた可能性も否定 できない.

なお，細粒分が $10 \%$ 以下の試料が存在しないことから も，一定量以上の細粒分を含むことが凍上被害の原因で 


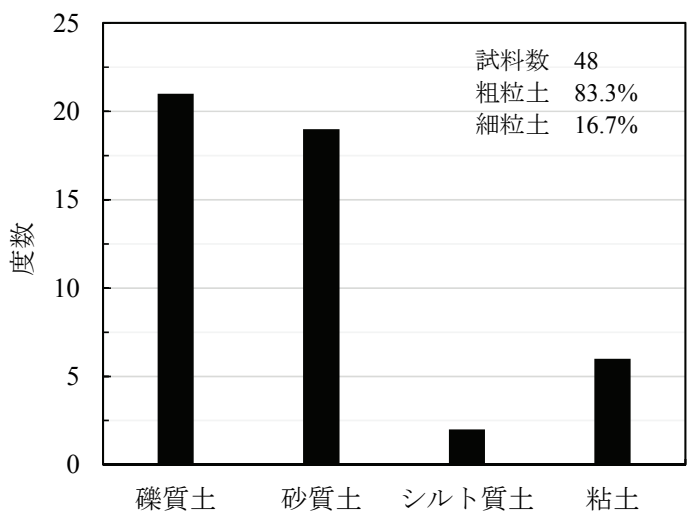

図-3 凍上被害箇所の土質分類

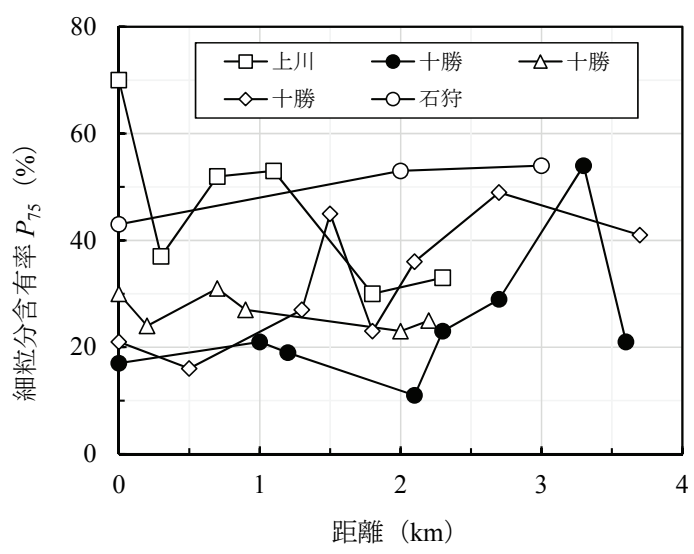

図-5 近接箇所での細粒分含有率の変動

あることは明らかである。

つぎに，図-5 はサンプリングが $5 \mathrm{~km}$ 以内で近接する 箇所を抽出し, 細粒分含有率の変動を示したものである. 数 $\mathrm{km}$ で変動の少ない路線がある一方で, 数 $100 \mathrm{~m}$ 範囲 で細粒分含有率が大きく変化する場合があることを示し ている。

一般に道路盛土の施工管理は現場密度によるものであ り, 所定の締固め度を満たせば, 通常の管理で細粒分含有 率に注目寸ることはない，さらに，CBR の基淮を満たせ ば路床とすることも可能である.

しかし，凍上の面から考えると細粒分含有率が局所的 に変化すると不同凍上を起こし，路面の段差や波打ちに つながる恐れもある. 今後の課題であるが, 細粒分含有率 の変動に着目することは凍上被害を考察する上で重要な ポイントになると考えられる.

図-6 は液性限界の分布である。既往の研究から，凍上 性とコンシステンシー限界については, 液性限界との相 関が知られている ${ }^{13)}$. 本結果の $w_{\mathrm{L}}$ の平均 $(\mathrm{NP}$ を除く) は $50 \%$ 程度であり，一般的な粘性土 ${ }^{12}$ に比較すると低め の值である.これは, 本試料が $2 \mathrm{~mm}$ 以下を対象としたた め, $0.425 \mathrm{~mm}$ 以上の砂分を多く含んだことが原因と考え られる. 全体の傾向としては， $w_{\mathrm{L}}<50 \%$ の低液性限界の

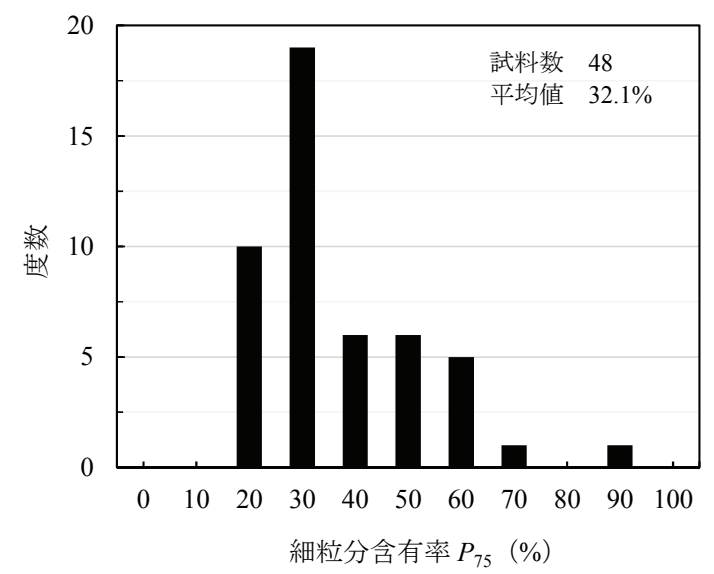

図-4 細粒分含有率の分布

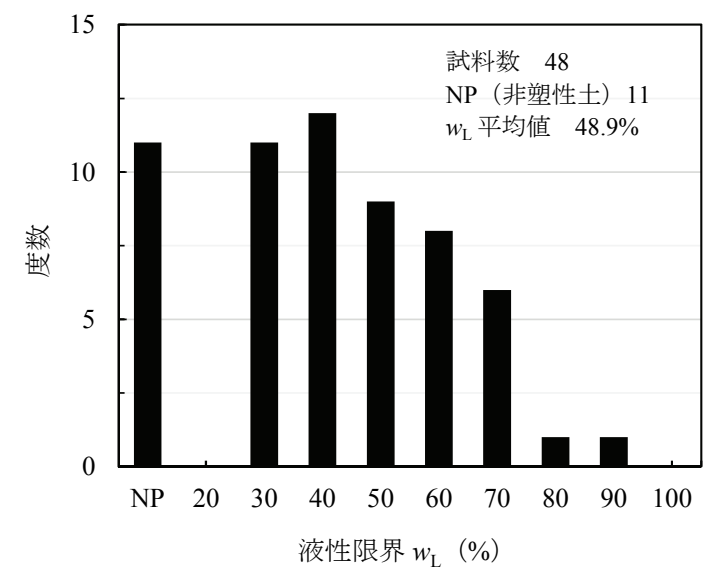

図-6 液性限界の分布

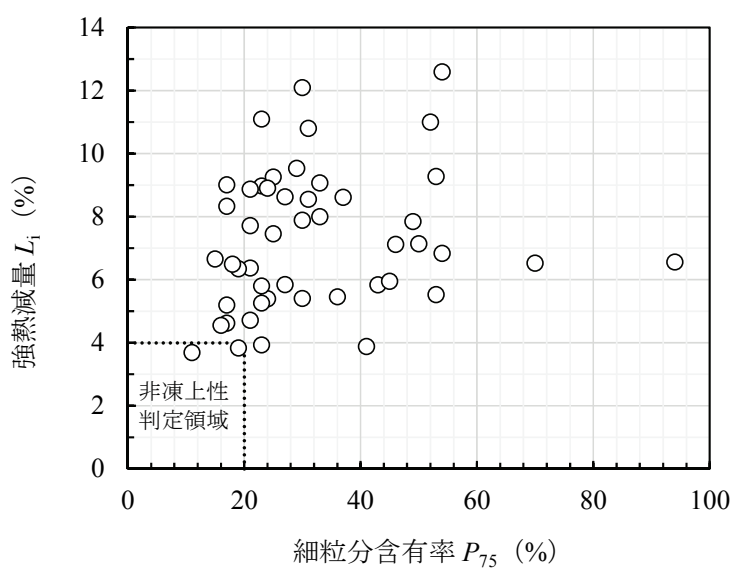

図-7 細粒分含有率と強熱減量の関係

試料が多く, NP まで含めると 7 割程度 (32 試料) を占め ていた．凍上性に応じて液性限界は高くなると予想した ため, 低液性限界の割合は少ないと思われたが, 本結果は 相反していた。

図-7 は細粒分含有率と強熱減量の関係である.これは, 過去に火山灰土の凍上性簡易判定法 11) として提案された ものであり，細粒分含有率 $20 \%$ 以下でかつ強熱減量 $4 \%$ 以下であれば非凍上性に判定できるとした。 


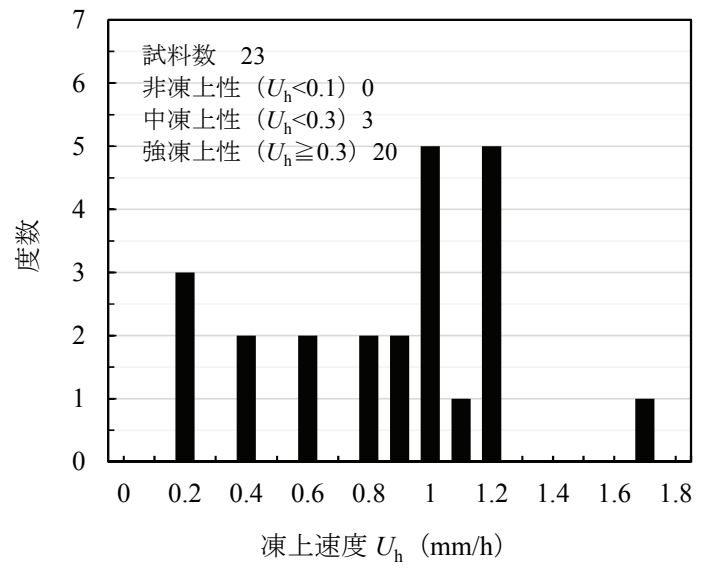

図-8＼cjkstart凍上被害を受けた路床土の凍上速度

本試料群は凍上被害箇所から採取したものであり，一 見すると凍上性に判定される領域に分布することから， 的確な判定のような印象を受ける. しかし, この判定法の 問題は凍上性領域に非凍上性が含まれることであり, 非 凍上性領域に凍上性は含まれないことが分かっている ${ }^{14)}$. さらに, 細粒分含有率では凍上性と非凍上性を区分する ことが難しい一方で，強熱減量が両者を区分可能である としている ${ }^{14)}$. したがって, 注目すべきは, 細粒分含有 率が $20 \%$ 以下のものが多く含まれるのに対して, 強熱減 量は 4 \%を境界として簡易判定法の閾値とほぼ一致する 点である. なお, 両指標と凍上性との相関については改め て(3)で詳細を述べる.

\section{（2）凍上被害を受けた路床土の凍上性}

図-8 は本試料（凍上被害を受けた路床土）の凍上速度 の分布である. 非凍上性のものは含まれず, 23 試料中 20 試料が強凍上性に判定される. さらに, 凍上速度 $U_{\mathrm{h}}$ が 1 $\mathrm{mm} / \mathrm{h}$ 以上の極めて強い凍上性を示寸試料が半数程度含 まれていた.

今回の試料は，厳密には凍上被害箇所直下から採取し たものではなく，また密度も現場条件を再現していない． このため参考值であることは否めないが，広義には路床 土の凍上性と被害の関係を示した結果であると理解して おり, 今後の検討として $U_{\mathrm{h}}$ に応じた置換率の再考の足掛 かりになるものと考えている.

\section{(3) 物理的性質と凍上性の関係}

非凍上性となる置換材料の基準は，細粒分含有率を基 本としており，砂を例に挙げると $6 \%$ 以下と定めている ๑. 凍上は細粒分による現象であることから, 凍上の可能 性の有無は, 細粒分含有率で判定が可能である. しかし, 細粒分含有率から土粒子の特性すなわち凍上性の強弱を 判定することは不可能である.

前述の図-5 では, 細粒分含有率の局所的な変化とその

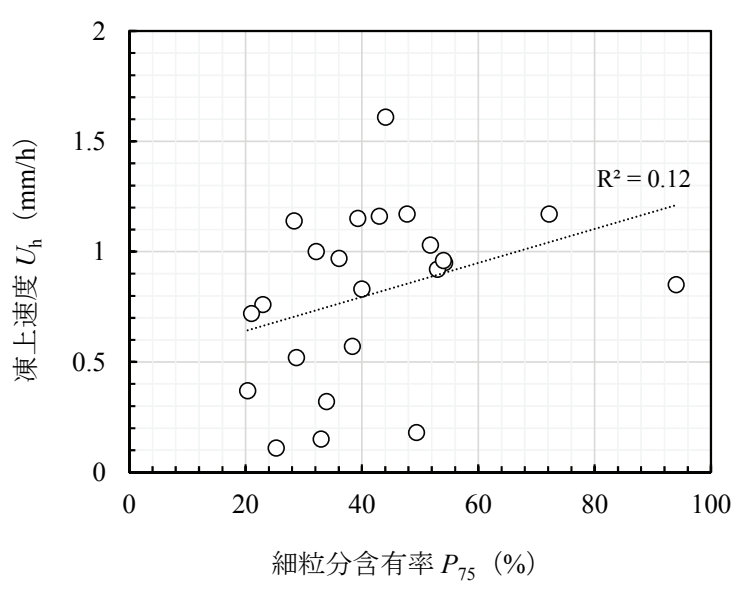

図-9＼cjkstart細粒分含有率と凍上速度の関係

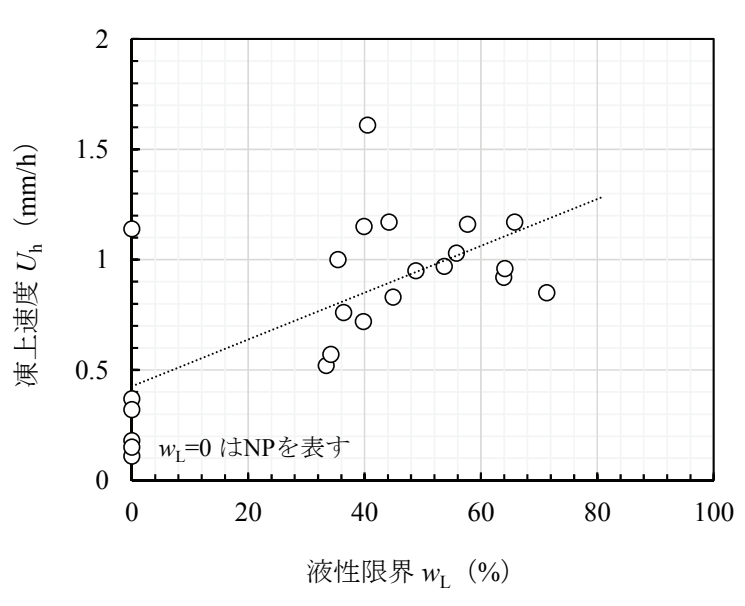

図-10 液性限界と凍上速度の関係

問題点に触れたが，この問題の本質は凍上性の局所的な 変化である. 仮に簡易的な指標によって路床の凍上性が 把握できれば，極端に凍上性の異なる路床土が偏在化す ることを抑制できる可能性がある.

そこで, 以降では各種物理指標と凍上性の関係をまと め, 凍上性の簡易判定法について検討する.

図-9 は細粒分含有率と凍上速度の関係である。一見し て明らかなように, 両者の相関は極めて低い. 細粒分含有 率の増加により凍上発生の可能性は上昇するため正の相 関となるが，細粒分含有率のみで涷上性を判定すること は不可能である.

図-10 は液性限界と凍上速度の関係である。ここでは, $\mathrm{NP}$ を便宜上 0 として表示している. 前述したように, 液 性限界は土粒子の物理化学的性質を反映するため, 凍上 性との関係が期待された. しかし, 両者も正の相関を示寸 ものの, バラつきが大きく判定指標には適さない.

図-11 は強熱減量と凍上速度の関係であり, 両者には明 確な正の相関がみられる. 図-7 の説明でも述べたように, 強熱減量は従来から凍上性との関係が示されており，そ の理由は, 凍上性の強弱を支配する不凍水量と深く関係 


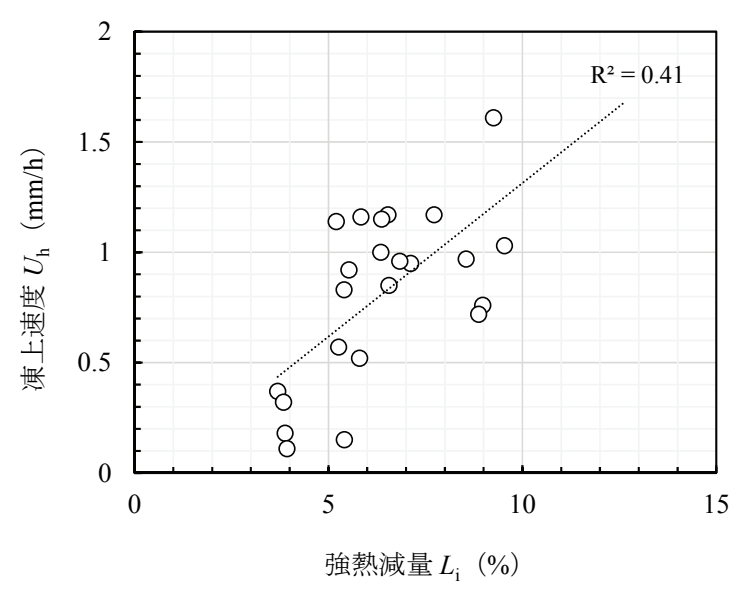

図-11 強熱減量と凍上速度の関係

表-3 GB 混合土の諸元

\begin{tabular}{c|c|c}
\hline & ガラスビーズ & 木節粘土 \\
\hline \hline 土粒子の密度 $\left(\mathrm{g} / \mathrm{cm}^{3}\right)$ & 2.527 & 2.572 \\
\hline 液性限界 $(\%)$ & --- & 54.6 \\
\hline 塑性限界 $(\%)$ & -- & 30.7 \\
\hline 粒径 $(\mathrm{mm})$ & $10,5,2,0.8$ & 0.008 (50\%粒径) \\
\hline 配合比率 & \multicolumn{2}{|c}{ 両者の割合を重量比で $10 \%$ ずつ変化 } \\
\hline
\end{tabular}

するためである，ただし，本結果の $\mathrm{R}^{2}$ 值をみると，さほ ど高い相関関係は得られていない. これは, 細粒分含有率 の違いを反映していないためと推察した. すなわち, 強熱 減量は細粒分の特性に依存する值であり, 同じ強熱減量 であっても細粒分含有率が異なれば，凍上性への影響度 が変化すると考えられる.

しかし，現時点は細粒分含有率の影響を評価する手法 が存在しない. 例えば, ある土を細粒分と粗粒分に分けて， 両者の配合比率を変えた場合, 凍上性は細粒分の割合に 応じて増大していくと予想される. ただし, その変化傾向 は不明である。

そこで，性状が安定した均質な細粒分と粗粒分を用い てその配合を変化させ，細粒分含有率が凍上に与える影 響を検証した.この検証には，これまで述べた試料とは別 にガラスビーズ (GB) と凍上性の木節粘土による混合土 を用いた. なお, この混合土は液性限界状態の木節粘土に GB を混ぜて $100 \mathrm{kPa} て ゙$ 圧密して作製した. GB 混合土の 諸元を表-3に, 図-12 に粒径加積曲線を示す. GB は最大 粒径を $20 \mathrm{~mm}(100 \%)$, 最少粒径を $0.425 \mathrm{mm（0 \% )} \mathrm{と}$ した直線粒度になるよう $10 \mathrm{~mm} \sim 0.8 \mathrm{~mm}$ の 4 種類の $\mathrm{GB}$ を配合し, 液性限界状態の木節粘土に $10 \%$ ずつ混合した。

図-13 は, GB 混合土の細粒分含有率と凍上速度の関係 である.この関係から, 両者は対数近似で表されることが 明らかとなった.この結果から, 細粒分含有率の違いを凍

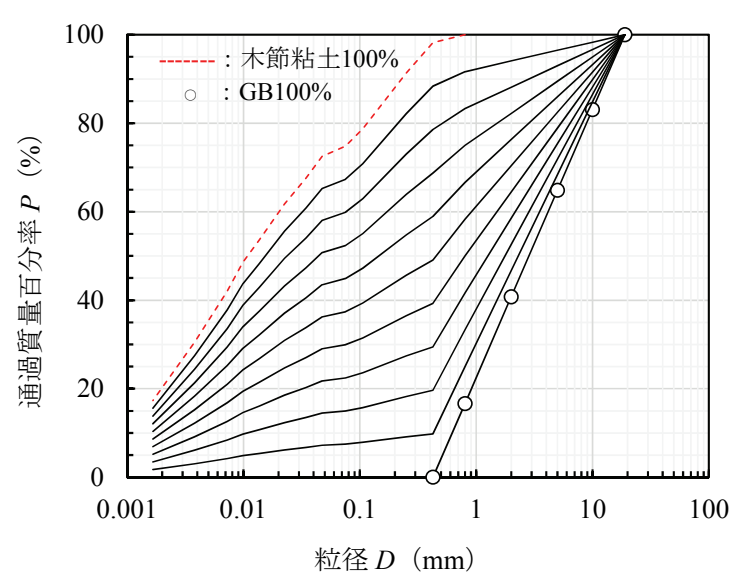

図-12 GB 混合土の粒径加積曲線

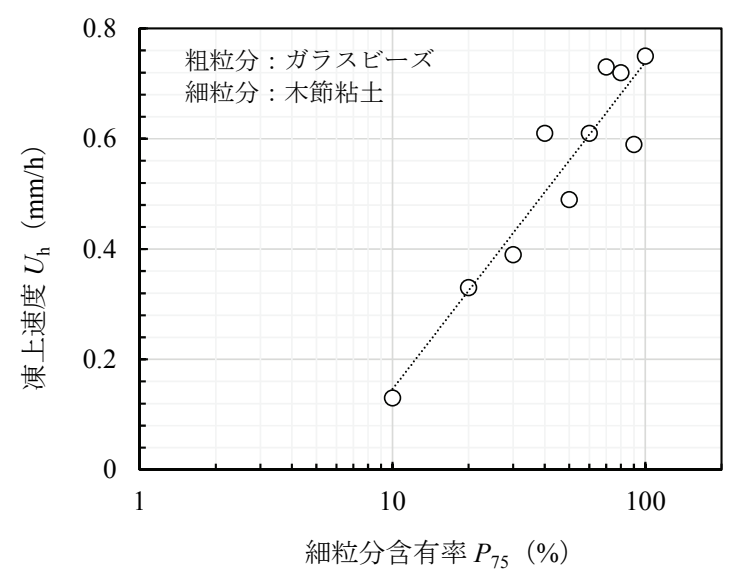

図-13＼cjkstart細粒分含有率による凍上速度の変化（GB 混合土）

上への影響度として反映させるには，細粒分含有率の対 数を用いることが有効であると判断した.

以上より, 強熱減量を凍上性の強弱を表す指標 (質的な 凍上リスク), 細粒分含有率を凍上性への影響度を表す指 標（量的な凍上リスク）と捉えて，両者を加味した凍上性 指標（Frost Susceptibility Index）を提案した.

$$
F_{\mathrm{si}}=L_{\mathrm{i}} \times \log P_{75}
$$

ここに, $F_{\mathrm{si}}$ : 凍上性指標, $L_{\mathrm{i}}$ : 強熱減量 $(\%), P_{75}$ : 細 粒分含有率 $(\%)$

凍上性指標と凍上速度の関係を図-14に示す.凍上に影 響する質的な性質と量的な性質を加味したことで，最も 高い相関関係を得ることができた. なお，この関係でも残 るバラつきについては, 供試体の状態量 (密度や飽和度の 違い) が影響していると考えられるが, 物理的性質のみで 凍上性の強弱を簡易に判定することが目的であり，その 目的に対する精度は得られたと考えている。 


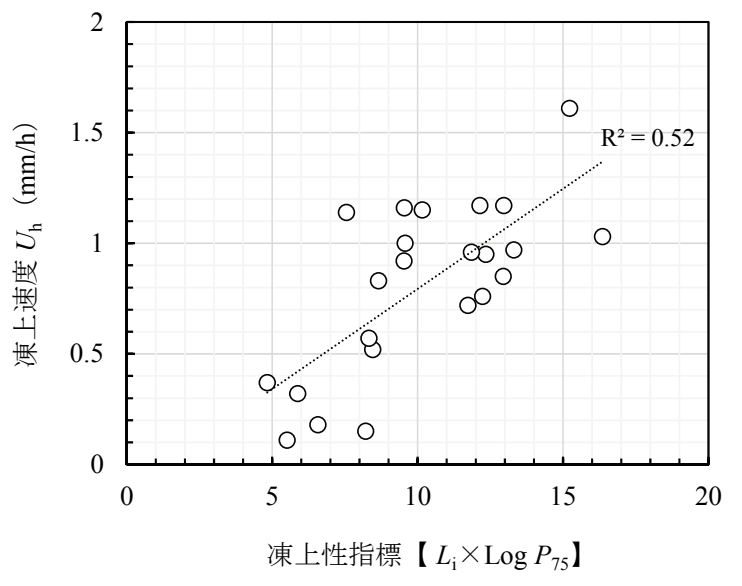

図-14 凍上性指標と凍上速度の関係

強熱減量と細粒分含有率は，凍上試験とは異なり簡易 に求められる土質指標である. このため, 凍上被害と路床 土の性状をさらに広域的に調査する際には，有効な手段 となる. また, 今後は本指標を現場管理に活用寸る方法に ついても検討を加える予定である.

\section{5. まとめ}

凍上被害を受けた北海道内の国道より路床土 (48 試料) をサンプリングし，凍上性および地盤工学的な特性につ いて考察した．結果は以下の通りである.

(1) 凍上被害箇所の路床土は $80 \%$ 以上が粗粒土であり, 粒度組成から考えると締固めに適した良質なものが 多く存在した.

（2）近接する箇所において細粒分含有率の変動を調べた 結果, 数 $100 \mathrm{~m}$ の範囲で細粒分含有率が大きく変化 する事例が確認された. 細粒分含有率の局所的な変 化は不同凍上を起こし, 路面の段差や波打ちにつな がる恐れも考えられる。

（3）凍上被害箇所功採取した本試料には，非凍上性の ものは含まれず, 23 試料中 20 試料が強凍上性に判定 され，そのうち極めて強い凍上性を示寸試料が半数 程度含まれていた。

（4）細粒分含有率と凍上速度の相関は極めて低く, 細粒 分含有率のみで涷上性を判定することは困難である。

（5）液性限界は土粒子の物理化学的性質を反映するため, 凍上性との関係が期待されたが，正の相関はみられ るものの, バラつきが大きく判定指標には適さない.
（6）強熱減量と凍上速度には，明確な正の相関がみられ るが, 高い相関関係は得られなかった。これは, 細粒 分含有率の違いにより, 凍上性一の影響度が変化す るためである.

（7）強熱減量を凍上性の強弱を表す指標（質的な凍上リ スク), 細粒分含有率を凍上性への影響度を表す指標 （量的な凍上リスク）と定義し, 両者を加味した凍上 性指標による簡易判定法を提案した。

\section{参考文献}

1) 亀山修，川端伸一郎，豊田邦男，川村 彰，笠原 篤 : 寒冷 地の高速道路における平坦性の季節変動に関する研究，土木 学会論文集，No.742/VI60, pp.51-60, 2003.

2) 亀山修一, 川端伸一郎, 豊田邦男, 川村 彰, 姫野賢治: 凍上 の影響を受けた高速道路の縱断プロファイル特性，土木学会 論文集，No.802/V69，pp.223-234，2005.

3) 川端伸一郎, 亀山修, 金井利浩, 冨澤 健, 石田眞二 : 寒冷 地における舗装のひび割れ被害の実態とその特徴，土木学会 舗装工学論文集，第 15 巻, pp.211-218，2010.

4) 日本道路協会 : 舗装設計便覽, pp.60-76, 2006.

5）伊福部宗夫 : 北海道における道路の凍上・凍結深さおよび置 換率に関寸る研究，土木試験所報告，Vol.26，1962.

6) 日本道路協会: 道路土工要綱 (平成 21 年度版), pp.194-218, 2009.

7) 久保 宏: 積雪寒冷地舗装の涷上対策, 土木学会誌, Vol.64, No.2, pp.10-16, 1979.

8）地盤工学会 : 凍上性判定のための土の凍上試験，JGS01722009, 2009.

9）日本道路協会 : 道路土工排水工指針，資料-10，pp.238-243, 1987.

10）川端伸一郎, 石川達也, 豊田邦男, 山内智, 亀山修一:土の 凍上性評価に与える凍結方法および共試体寸法の影響，土 木学会論文集 E1，Vol.69，No.3，I_191-I_198， 2013.

11）小山道義, 高橋毅, 川井優: 火山灰の凍上性について, 土と 基䃈 Vol. 13， No. 11，pp.29-32， 1965.

12）地艋工学会 : 地盤材料詿験の方法と解説，pp.137-152, 2009.

13）片岡哲之, 緒方信英 : 地盤の凍結・凍上特性 - 凍上特性と土 質常数の相関 - , 電力中央研究所報告, 385053, 1987.

14）川端伸一郎, 池田晃一, 神谷光彦: 北海道粗粒火山灰土の物 理的性質と凍上性の関係, 土木学会論文集 C, Vol.62, No.1, pp.35-44, 2006.

(2019. 6. 13 受付) 


\section{GEOTECHNICAL PROPERTIES OF SUBGRADE SOILS DAMAGED BY FROST HEAVE}

\section{Shinichiro KAWABATA, Shuichi KAMEYAMA and Atsuko SATO}

We collected 48 samples of subgrade soil from a frost-heaved place of a national road in Hokkaido and investigated them for both frost susceptibility and geotechnical properties. We found that more than $80 \%$ of the subgrade soil samples taken at frost-heaved locations were coarse-grained, and many were of high quality suitable for compaction. An experiment of the variation in the fine fraction of such samples, however, revealed cases of marked variation over stretches of several hundred meters, raising concerns that differential frost heave could result in an uneven or bumpy roadway surface. None of the subgrade soil samples collected from the frostheaved locations was judged to be non-frost susceptible. Most were instead judged to be frost susceptible, with many having high frost susceptibility. We examined several indices to determine their suitability as convenient measures of frost susceptibility and found that combination of ignition loss (a qualitative indicator of frost-heave susceptibility) and a fine fraction (a quantitative indicator of frost-heave susceptibility) was effective. 